\begin{tabular}{|c|c|c|}
\hline & PORT SAID ENGINEERING RESEARCH JOURNAL \\
\hline Faculty of Engineering - Port Said University \\
\hline No. 2 & September 2020 & pp. 97-105 \\
\hline
\end{tabular}

\title{
Design and Economics of a PV-based Pumped Hydro Storage Station in Rural Distant Areas in Egypt
}

\author{
Hilmy Awad ${ }^{1}$, Nadia S. Mohamed ${ }^{2}$, Ahmad M. Atalla ${ }^{3}$, Hassan Mahmoud ${ }^{4}$ \\ Received: 16 June 2020; Accepted: 30 August 2020
}

\begin{abstract}
Although photovoltaic (PV) Energy is a viable solution and clean energy source, it is an intermittent source and certainly needs energy storage, particularly in the case of off-grid applications. Batteries are normally used as the common energy storage, despite all their demerits. This paper presents a preliminary design and cost estimate of a potential candidate for energy storage applications, which is the PV-based Pumped-Hydro Energy Storage (PHES). The proposal is suited for application in rural and distant areas, where the public electric grid is not easily accessible. The basic idea is that the required load demand is fulfilled by PV panels during the day. During the periods of high insolation, the PV panels are also used to pump water to a $31-\mathrm{m}$ height tank. Then, at night or in periods of low insolation the water is allowed to flow downwards operating a hydro generator. Based on the average expected load (irrigation and domestic) of distant locations in Egypt, the PV panels and reversible pumps have been sized together with other system components. A cost estimate has been done to compare batteries and PHES for the average lifetime of the two systems. The cost estimate revealed that the PHES would be economically viable after 23 years of service. The system can be easy to extend to a larger scale by adding more reversible pumps and PV panels.
\end{abstract}

Keywords: photovoltaic; hydro storage; electric grid

\section{INTRODUCTION}

As the electricity demand increases continuously, research on reliable, efficient, and clean energy sources is advancing globally [1]. However, it is not an easy task to achieve the foregoing requirements because either fossilfuel-energy or renewable-energy sources have their merits and demerits $[2,3,4,5]$. The basic challenge of renewable energy sources is their intermittent nature. Otherwise, they provide a clean and consequently an environmentfriendly solution. To overcome this intermittent nature, two directions have been followed: construction of hybrid-energy source $[6,7,8]$ and integration of efficient energy storage $[9,10,11]$.

In the case of off-grid renewable energy sources, energy storage is not optional. There are many technologies of energy storages such as: Batteries, Ultra Capacitors, Flywheel [12,13,14], Superconducting Magnetic Energy [15,16,17], Molten Salt [19,20], Compressed Gases [21,22], and Pumped Hydro Storage Systems $[23,24,25,26]$. Batteries have been and still the most common option as storage for renewable energy applications [27,28,29].

${ }^{I}$ Hilmy Awad, , Assistant Professor, Faculty of Technology and Education, Helwan University, Cairo, Egypt, Corresponding Author,email: hilmy_awad@yahoo.com

${ }^{2}$ Nadia Shokry, Teacher, Ministry of Education, Cairo, Egypt.

${ }^{3}$ Ahmad Atalla, Professor, Faculty of Engineering, Ain Shams University, Cairo, Egypt.

${ }^{4}$ Hassan Mahmoud, Ph.D., Vice Minister, Electric Energy Authority. DOI: $10.21608 /$ pserj.2020.32005.1042
However, their limited power ratings, regular replacement, and maintenance cost represent a challenge for the implementation of a long timescale $[30,31,32,33]$. Other technologies of energy storage have been also reported in the literature such as fuel cells and supercapacitors [33].

The decision on which energy storage to integrate into renewable energy systems relies on many factors such as Energy and Power Densities (W.h/kg, W/kg), Cycle Efficiency (\%), Self-Charge/Discharge Characteristics, Life cycles (number of cycles), Chronological lifecycle and Power Ratings [34,35,36,37]. In some cases, the geographical location plays an important role in this issue [38,39] which favors the option of Pumped Hydro Energy Storage (PHES). Major advantages of PHES include longtime cost regain, high sustainability level, and its ability for large scale implementation. Moreover, PHES constitutes $94 \%$ of the globally installed capacity of energy storage [40]. This paper presents such a situation in the east of Al-Owainat area, Egypt due to the fertility of its soil, the high availability of solar energy, and the presence hills and the Nubian sandstone reservoir in it $[41,42]$.

The main aim of the paper is to present the preliminary design and cost estimation of a complete system that involves PV panels and PHES to feed electricity to 10 domestic users as well as irrigation of 50 acres as a case study to investigate its feasibility, compared to battery energy storage. Section II of this paper presents a description and layout of the site. In Section 3, the design guidelines of the whole system are presented. Section 4 
displays the cost estimation of the main system components with and without batteries. Results and discussion are presented in Section 5.

\section{DESCRIPTION AND LAYOUT OF THE SITE}

\subsection{Site Location}

Al-Owainat is in the southwestern part of the Arab Republic of Egypt, $365 \mathrm{~km}$ south of Dakhla, New Valley Governorate [43]. East Al-Owainat is one of the distinct areas in terms of soil type, suitability for cultivation, water quality and abundant quantity, in addition to the climate that allows the cultivation of the finest and most valuable strategic and economic cultivations such as alfalfa, wheat, corn, barley, palms, oil crops, medicinal and aromatic plants [44]. Fig. 1 displays a part of Egypt's map showing the area of East Al-Owainat (circled).

East Al-Owainat area is characterized by the presence of the Nubian sandstone reservoir, as it is one of the largest underground reservoirs in the world in terms of its horizontal and vertical extension as well. The saturated thickness of the tank ranges between $200 \mathrm{~m}$ in the east of $\mathrm{Al}$-Owainat in the far south and gradually increases in the northern direction until it reaches more than $300 \mathrm{~m}$ in Farafra Oasis. The groundwater available in this reservoir is of good quality and the percentage of salts therein is lower $[41,42]$.

\subsection{Preliminary Site Layout}

The site consists of 10 rural houses, 50 acres to be cultivated, a groundwater well, a storage tank for drinking and irrigation water, an electric machine for grinding agricultural cereals that be used during the day or at night, electric water pumps for irrigation by spraying that work at night, a hydroelectric power station as it is one the most efficient and effective energy solutions [45]. The hydroelectric power station consists of an overhead tank, a lower tank, water turbines. There is also a photoelectric (PV) station that consists of several photovoltaic modules - three-phase inverter and submersible pumps, three-phase electric transformer - automatic connection plate to separate and switching panel.

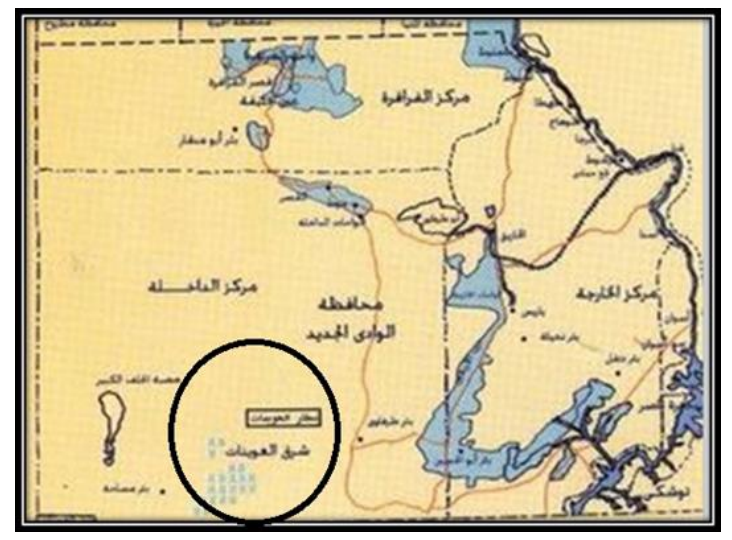

Figure. 1. Part of Egypt's map with the area of East Al-Owainat circled.
The groundwater well has submersible pumps to pump water from the underground well to the upper tank only once per day. The overhead tank is built next to the underground well over a hill. Water is pumped from the well to the overhead tank whenever the water level in the tank decreases due to evaporation. There is another lower tank built on the slope of the upper tank such that the water circulates between them in a closed-loop where the water is used to generate electricity during the night or when the PV output is not enough to feed the loads. The groundwater well feeds another reservoir to supply the area with the water needed for drinking, irrigation, household uses and irrigation as well as for rural animals.

\section{SYSTEM DESIGN}

\subsection{Design Steps}

The first step of the design has been the identification of a suitable location to employ its topography aiming to reduce the total capital cost of the project. As said in Section II, East Al-Owainat was selected due to explained reasons. Then, the required data regarding all water requirements and the electrical loads were collected to calculate: 1) capacities, heights, and locations of the two water reservoirs, 2) the power ratings of the PV panels as well as the hydraulic station. Subsequently, the capacities, numbers, and types of water turbines were identified. All required calculations were done to complete the design of the system as follows.

\subsection{Calculations}

\subsubsection{Hydraulic Power Station}

To minimize the system cost, a reversible pump is selected to play the role of a water pump and a water turbine as well. The use of reversible pumps in renewable energy applications has been reported in the literature such as $[46,47,48]$. The first step in the design was to estimate the daily energy consumption of an average rural house, for which the details are given in Appendix A, where a diversity factor was taken as 1.3 and group diversity factor was taken as $1.1[49,50]$. Based on these calculations, the power required for 10 homes is $3252.7 \mathrm{~W}$.

The next step is to determine the daily energy consumption of the whole site. There are two main loads: agricultural grain milling machine; Irrigation water pump for Fixed spraying. Details of these loads are given in Appendix B. Based on the assumed loads; the total power required for the selected electrical machines per day is 790.9 W. Consequently, the total power required is $3252.7+790.9=4043.6$. Considering a power loss of $30 \%$ in ally system components, the power required is then $4043.6 \times 1.3=5256.7 \mathrm{~W}$. The water flow rate can be calculated using eq. (1) as [21]:

$$
P=\eta \times \rho \times Q \times g \times H_{\text {net }}
$$


Where

$P=$ generator output $=5256.7 \mathrm{~W}$

$\eta=$ Efficiency of generating units (turbine + generator), assumed as $90 \%$

$Q=$ Water flow through the turbine (Discharge) in $\left(\mathrm{m}^{3} / \mathrm{sec}\right)$

$\rho=$ Density of water $=1000 \mathrm{~kg} / \mathrm{m}^{3}$

$H_{\text {net }}=$ net head of water (the difference in water level between upstream and downstream of the turbine) $=30 \mathrm{~m}$ $g=$ Gravitational acceleration $=9.81 \mathrm{~m}^{2} / \mathrm{s}$

Substituting all the above values gives $Q=0.02 \mathrm{~m}^{3} / \mathrm{s}=$ $72 \mathrm{~m}^{3} / \mathrm{h}$. This implies that if the pumps work for hours, they will store $432 \mathrm{~m}^{3}$ of water. Assuming two autonomous days, they should be able to store $864 \mathrm{~m}^{3}$ of water.

\subsubsection{Pump Calculations}

As the efficiency of Francis turbine is the highest among other turbine types and it is the most commonly used in hydropower plants [51], it is selected in this work. More precisely, Francis-type reversible pump-turbine has been selected to minimize the total cost, as stated in Section II. The pump must raise the water against the net vertical head in addition to the hydraulic losses due to friction. Such losses are expressed in meters and they depend on the diameter and length pipes as well as the shape of connections. However, as preliminary calculations, they can be taken as 5-10\% of the required water head. Thus, they were considered here to be $7 \%$ of the $30-\mathrm{m}$ head. Consequently, the total required head by the pump is $30+0.07 *(30+1)=33.17 \mathrm{~m}$, where one meter is added that represents the height of the water tank. The power of the pump is calculated using eq. (2) as follows.

$$
P_{h}=\frac{Q \rho g H_{\mathrm{tot}}}{3600 \times 1000}
$$

Where $Q$ is the volumetric flow rate of water through the pump $(\mathrm{m} 3 / \mathrm{h}) . H_{\text {tot }}$ is the total head required by the pump. In Egypt, the sun hours range from 6-10 hours [52]. A value of 9 hours is considered here for sun hours. Thus $Q=864 / 9=96 \mathrm{~m}^{3} / \mathrm{h}$. Then the pump power is 8.7 $\mathrm{kW}$ or $11.7 \mathrm{hp}$. Considering that the efficiency of the associated electric motor is 0.85 [53,54], the required electric power is $10.2 \mathrm{~kW}$ or $13.7 \mathrm{hp}$. As the nearest commercially available turbine is $6 \mathrm{~kW}$ [55]. Thus, two of these turbines are selected.

\subsubsection{Calculations of the PV System}

The PV panels are required to feed: 10 houses, water pumps for drinking and irrigation, and other electrical machinery in the site such as gain grinding machine and irrigation water pump for Fixed spraying.

\subsubsection{Calculations of the water pumps}

The design process of the water pumps follows the same procedure as the hydraulic turbine that was presented in Section B.2. First, the water flow rate must be determined. This necessitates the estimation of the daily water amounts of drinking and irrigation. All relevant calculations are given in Appendix C. Based on the calculations in Appendix $\mathrm{C}$, the amount of water needed to be stored for irrigation and drinking is $210 \mathrm{~m}^{3}$. As the sun hours are 9 hours as in Section B1, the water flow rate is $210 / 9=23.3 \mathrm{~m}^{3} / \mathrm{h}$. Knowing that the depth of the well is $30 \mathrm{~m}$ and the vertical height is $30 \mathrm{~m}$, and considering $7 \%$ hydraulic losses, the total dynamic head required by the pumps is $65.27 \mathrm{~m}$. Reapplying eq. (3) to determine the power of the pump yields that the required pump should have a rating of $4.1 \mathrm{~kW}$ or $5.5 \mathrm{hp}$. Considering a motor efficiency of $85 \%$, the power rating of the required motor is $4.8 \mathrm{~kW}$ or $6.4 \mathrm{hp}$. Here, it is preferred (for repair and maintenance purposes) to have two submersible pumps, each of them is rated at $3.25 \mathrm{hp}$ and $380 \mathrm{~V}$.

\subsubsection{Sizing of the PV Panels and Inverter}

The PV panels will feed all the electrical loads as shown in Table 1.

Table 1. Electrical loads required energy for the site

\begin{tabular}{|l|c|c|c|c|}
\hline $\begin{array}{l}\text { Electric } \\
\text { Loads }\end{array}$ & $\begin{array}{c}\text { Power } \\
\text { [W] }\end{array}$ & $\begin{array}{c}\text { Quantit } \\
\mathbf{y}\end{array}$ & $\begin{array}{c}\text { Hour } \\
\text { s/day }\end{array}$ & $\begin{array}{c}\text { Energy } \\
\text { Wh/day }\end{array}$ \\
\hline Power pump & 5219.9 & 2 & 9 & 93958.2 \\
\hline $\begin{array}{l}\text { Submersible } \\
\text { pump }\end{array}$ & 2423.5 & 2 & 9 & 43623 \\
\hline $\begin{array}{l}\text { Agricultural } \\
\text { grain milling } \\
\text { machine }\end{array}$ & 2237.1 & 1 & 1 & 22371 \\
\hline $\begin{array}{l}\text { Total Required Energy for Electrical } \\
\text { Machines }\end{array}$ & $\mathbf{1 3 9 8 1 8 . 3}$ \\
\hline
\end{tabular}

The total amount of energy required from the PV panels is 139818.3 plus the energy of the 10 houses as in appendix A, i.e. Total energy $=139818.3+111162=251$ $\mathrm{kWh}$. Compensating for $30 \%$ electrical losses, the required energy becomes $326.3 \mathrm{kWh}$. From Table 1, the total amount of power is $17.5 \mathrm{~kW}$. Taking a diversity factor of 1.1 , the required power for the electrical machines becomes 17.5/1.1 = $15.9 \mathrm{~kW}$. Adding the power required for 10 houses gives the total amount of power as $15.9+3.25=19.15 \mathrm{~kW}$.

The size of the PV panels is calculated (based on 9 sun hours) as $326.3 / 9=36.25 \mathrm{~kW}$. Selecting a $260-\mathrm{W}$ PV module yields the number of modules as $36.25 / 0.26 \approx$ 140 modules. The characteristics of the selected module are given in Appendix D. The system voltage was identified as 400 . Hence, the number of series modules $=$ $400 / 30.8=13$ modules, and consequently the number of strings is $140 / 13 \approx 11$. This gives a total of 143 modules.

The total amount of the required electric power is 19.15 $\mathrm{kW}$. Adding a safety margin of $30 \%$ gives the total power should be supplied with the inverter as $19.15 \times 1.3=$ $24.9 \mathrm{~kW}$. The nearest commercially available inverter is $27 \mathrm{~kW}$. 


\subsection{Batteries and Charge Controller}

Although the proposed system is essentially a replacement or an alternative to the battery banks, the sizing of batteries and their charge controllers has been done for the sake of comparison between the two alternatives in terms of the total cost. The batteries are size based on the total energy required by all the operated loads, which in this case is $132.5 \mathrm{kWh}$ according to the data given the appendices. Assuming $30 \%$ electrical losses, the total energy would be $172.25 \mathrm{kWh}$. Assuming 2 days of autonomy, the total required energy by the batteries would be $344.5 \mathrm{kWh}$.

If the allowed depth of charge is $50 \%$ and the battery voltage is $12 \mathrm{~V}$, then the total capacity of the batteries would be $(344.5 \mathrm{k} /(0.5 * 12))=57417$ Ah. Choosing a 200 Ah battery yields that the total number of batteries $57417 / 200 \approx 288$ batteries. Since the system voltage is $400 \mathrm{~V}$ and the battery voltage is $12 \mathrm{~V}$, then the series batteries are $400 / 12 \approx 34$ batteries. Hence the number of battery strings is $288 / 34=8.47 \approx 9$ strings. This gives a total of $34 \times 9=306$ batteries.

The current rating of the charge controller(s) is directly related to the short-circuit current and the number of strings of the PV modules. According to the data given in Section 3.2 and allowing a $30 \%$ safety margin, the current of the charge controller is calculated as Icc $=8.91$ $\mathrm{x} 11 \mathrm{x} 1.3=127.41 \mathrm{~A}$. Selecting a 50-A charge controller implies that the number of needed charge controllers is 3 .

\section{ESTIMATION OF THE STORAGE- SYSTEM COST}

In this Section, the cost of the storage system is estimated for the two alternatives: PHES and Batteries with charge controllers. The main objective of the Section is to able to compare the two alternatives and determine the number of years after which the PHES would be economically visible.

\subsection{Cost of Batteries and Charge Controllers}

\subsubsection{Cost of Components}

Most of the cost elements here are based on the local currency (LE) according to the local market in Egypt. However, some components are not available in local currency and only available in USA Dollars. So, the estimation may be slightly different due to the fluctuation of the Egyptian Pound against the USA Dollar. At the time of estimating the cost, it was 1 \$ -US $\mathrm{A}=15.8 \mathrm{LE}$.

The designed batteries in this work are rated $200 \mathrm{Ah}$ and their number is 297 batteries as calculated in Section B3.3. According to [56], the price of a 200-Ah battery is $206 \$$ which is equivalent to $3254.8 \mathrm{LE}$. Then the total price of the batteries is 967k LE. Regarding the charge controllers and according to [57], the price of a 50-A charge controller is $11.30 \$$ which is equivalent to 178.54 LE. Hence the cost of 3 charge controllers is 535.62 LE, which is insignificant compared to the cost of batteries, i.e, the total cost of the storage system is $967 \mathrm{k}$ LE, approximately.

\subsubsection{Cost of Maintenance of Batteries}

To be able to estimate the total cost of batteries and the cost of a $\mathrm{kWh}$ produced by them, it is necessary to identify the lifetime of both batteries and PHES. According to [58], the lifetime of PHES ranges from 50 to 150 years at almost no deterioration of performance. In this work, the lifetime of PHES is considered 80 years as reported in [58]. On the other hand, the batteries are usually replaced every 5 years of service [59]. Normally, the batteries are nor replaced rather repaired. Thus, only the cost of replacement is considered. The price of battery increases by $5 \%$ every year as reported in [60]. Since the batteries will be replaced every 5 years, they would be replaced 16 times based on the assumed lifetime of the PHES. Although the technology of batteries is quickly developed, there is no reliable source that presents how the development of technology would affect their prices. Therefore, the cost replacement is calculated based on the current price. The replacement cost over the 80 years is calculated through the following steps.

1- The battery price (967 k LE) is multiplied by the increase rate of 1.05 and then the price is calculated each year till 80 years.

2- The prices of batteries in the 5th multiple years are summed. Hence, the replacement cost of the batteries is $206.5 \mathrm{M} \mathrm{LE}$.

The replacement cost of the charge controller is calculated similarly and found to be 0.114 M LE. Hence, the total replacement cost is 206.64 M LE.

\subsection{Cost of PHES}

\subsubsection{Cost of Two Tanks}

The tanks are cylindrical with a diameter of 14 meters and a height of 6 meters. Based on the local market and resources, the cost of one water is $4 \mathrm{M} \mathrm{LE}$, which implies that the total cost of the two tanks is $8 \mathrm{M} \mathrm{LE}$.

\subsubsection{Cost of Reversible Pumps}

One three-phase, 380-V, 6-kW reversible pump costs 0.316 M LE [55]. Then, two pumps cost 0.632 M LE. As the reversible pumps are designed to withstand high pressures and continuous operation, there is no replacement cost [62,63]. However, according to [61], there is an operational cost of PHES that ranges from 6 to 43.3 US $\$$ per $\mathrm{kW}$ per year. Adding the highest value of this cost yields the total cost of the PHES is to be 9.29 MLE over the 80-years lifetime.

\section{RESULTS AND DISCUSSIONS}

Two alternatives have been studied to store the energy during the day and deliver it during the night or in cloudy days: pumped hydro energy storage (PHES) and batteries with charge controllers. Table 2 shows a 
comparison between the two alternatives in terms of components and costs. It is important noting that the inflation rate of the currency was not considered in the calculations, as it would affect both alternatives equally.

Table 2. Comparison between PHES and Batteries

\begin{tabular}{|l|l|l|}
\hline Item & PHES & Batteries \\
\hline Components & $\begin{array}{l}\bullet 2 \text { reversible } \\
\text { pumps, } 6 \\
\mathrm{~kW}, 380-\mathrm{V}, \\
\text { three-phase } \\
\bullet 2 \text { water tanks }\end{array}$ & $\begin{array}{l}\text { 200-Ah each } \\
\bullet\end{array}$ \\
$\begin{array}{l}\text { controllers, 50-A } \\
\text { each }\end{array}$ \\
\hline $\begin{array}{l}\text { Capital Cost } \\
\text { in M LE }\end{array}$ & 8.632 & 0.9667 \\
\hline $\begin{array}{l}\text { Lifetime } \\
\text { (years) }\end{array}$ & 80 & 5 \\
\hline $\begin{array}{l}\text { Replacement } \\
\text { Time (years) }\end{array}$ & NONE & 5 \\
\hline $\begin{array}{l}\text { Replacement } \\
\text { cost per year } \\
\text { in M LE }\end{array}$ & NONE & $\begin{array}{l}5 \% \text { increase. The } \\
\text { first replacement } \\
\text { cost is: } \\
0.9667 \times 1.05^{5}\end{array}$ \\
\hline $\begin{array}{l}\text { Operational } \\
\text { and } \\
\text { Maintenance } \\
\text { cost per year } \\
\text { in M LE }\end{array}$ & 0.0082 & $\begin{array}{l}\text { Included in the } \\
\text { battery price }\end{array}$ \\
\hline $\begin{array}{l}\text { Total cost } \\
\text { over the 80 } \\
\text { years } \\
\text { M LE }\end{array}$ & 9.29 & 206.64 \\
\hline
\end{tabular}

It is clear from Table 2 that the cost of batteries increases exponentially as the time advances while the cost of PHES is almost constant. Plotting the two costs per 5 years as displayed in Fig. 2 indicates that 23 years is the time after which the PHES becomes economically better than batteries. Since the lifetime of PHES is moderately taken as 80 years, the PHES proves to be a valuable solution to the energy storage problem. One more advantage of PHES over batteries is the environmental impact where the disposal of batteries requires careful attention [64].

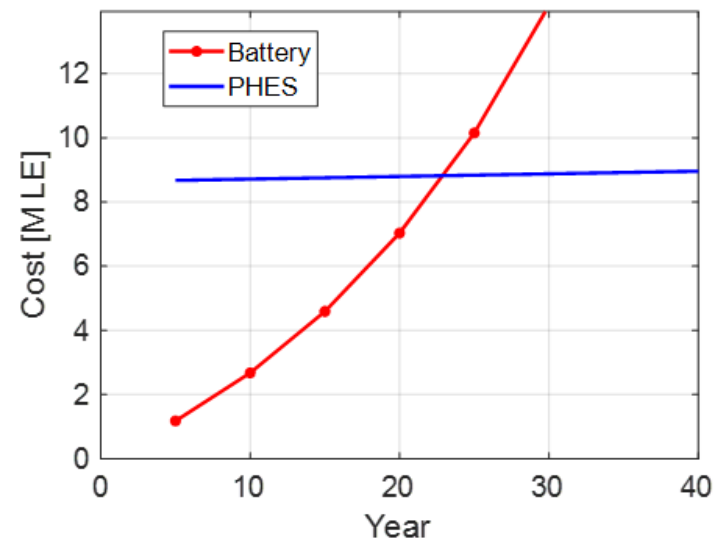

Figure. 2. Cost of PHES and Batteries per 5 years

\section{CONCLUSIONS}

The feasibility of a pumped hydro energy storage system (PHES) as an energy storage solution has been investigated for the implementation in Egypt for rural and distant regions. Exploring the topography of south Egypt has identified the Al-Owainat area as a potential candidate for the installation of PHES to feed 10 houses and irrigate 50 acres. The design of the PHES included two reversible pumps that have dual duties as a pump and water turbine for electricity generation. It also included the design of two water tanks. The PHES cost has been compared against the cost of an equivalent system of batteries and charge controllers. Preliminary calculations of the two systems revealed that 23 years is the breakeven point after which the PHES becomes economically visible. Not only economic issues but also environmental impacts favour the PHES solution.

\section{CREDIT AUTHORSHIP CONTRIBUTION STATEMENT:}

Dr. Hilmy Awad: Conceptualization, Original draft, and Software

Nadia Shokri: Methodology, Calculations

Prof. Ahmad Atalla: Supervision and Guidance

Dr. Hassan Mahmoud: Field Data and Guidance

\section{DECLARATION OF COMPETING INTEREST}

The authors declare that they have no known competing financial interests or personal relationships that could have appeared to influence the work reported in this paper.

\section{REFERENCES}

[1] OECD Green Growth Studies: Energy @ OECD 2011, available at: https://www.oecd.org/greengrowth/greeningenergy/49157219.pdf

[2] M. Ş. Üney and N. Çetinkaya, "Comparison of $\mathrm{CO} 2$ emissions fossil fuel-based energy generation plants and plants with Renewable Energy Source," Proceedings of the 2014 6th International Conference on Electronics, Computers and Artificial Intelligence (ECAI), Bucharest, 2014, pp. 29-34.

[3] Tyson Stevens, Renewable Energy vs Fossil Fuels: 5 Essential Facts, January 25, 2018, https://www.amigoenergy.com/blog/renewableenergy-vs-fossil-fuels/

[4] N. Anglani and G. Petrecca, "A comparison between fossil fuel and biomass distributed generation and utility," 2011 International Conference on Clean Electrical Power (ICCEP), Ischia, 2011, pp. 654-659.

[5] O. V. Marchenko, S. V. Podkovalnikov and S. V. Solomin, "Comparison of Competitiveness of Renewable and Non-Renewable Energy Sources in Russia, East Asian Countries," 2019 International Multi-Conference on Industrial Engineering and Modern Technologies (FarEastCon), Vladivostok, Russia, 2019, pp. 1-5. 
[6] M. S. Pranav, K. Karunanithi, M. Akhil, S. S. Vanan, V. M. Afsal, and A. Krishnan, "Hybrid renewable energy sources (HRES) - A review," 2017 International Conference on Intelligent Computing, Instrumentation and Control Technologies (ICICICT), Kannur, 2017, pp. 162-165.

[7] K. Anoune, M. Bouya, M. Ghazouani, A. Astito, and A. B. Abdellah, "Hybrid renewable energy system to maximize the electrical power production," 2016 International Renewable and Sustainable Energy Conference (IRSEC), Marrakech, 2016, pp. 533-539.

[8] M. H. Nehrir et al., "A Review of Hybrid Renewable/Alternative Energy Systems for Electric Power Generation: Configurations, Control, and Applications," in IEEE Transactions on Sustainable Energy, vol. 2, no. 4, pp. 392-403, Oct. 2011.

[9] A. Etxeberria, I. Vechiu, H. Camblong, J. M. Vinassa, and H. Camblong, "Hybrid Energy Storage Systems for Renewable Energy Sources Integration in microgrids: A review," 2010 Conference Proceedings IPEC, Singapore, 2010, pp. 532-537.

[10] P. F. Ribeiro, B. K. Johnson, M. L. Crow, A. Arsoy, and Y. Liu, "Energy storage systems for advanced power applications," in Proceedings of the IEEE, vol. 89, no. 12, pp. 1744-1756, Dec. 2001.

[11] J. D. Pinzón, "Current Development of Energy Storage Technologies for Advanced Applications in Sustainable Power Systems," 2019 FISEIEEE/CIGRE Conference - Living the energy Transition (FISE/CIGRE), Medellin, Colombia, 2019, pp. 1-6.

[12] A. A. Khodadoost Arani, G. B. Gharehpetian, and M. Abedi, "A Novel Control Method Based on Droop for Cooperation of Flywheel and Battery Energy Storage Systems in Islanded Microgrids," in IEEE Systems Journal, vol. 14, no. 1, pp. 1080-1087, March 2020.

[13] H. Akagi and H. Sato, "Control and performance of a doubly-fed induction machine intended for a flywheel energy storage system," in IEEE Transactions on Power Electronics, vol. 17, no. 1, pp. 109-116, Jan. 2002.

[14] G. O. Cimuca, C. Saudemont, B. Robyns, and M. M. Radulescu, "Control and Performance Evaluation of a Flywheel Energy-Storage System Associated to a Variable-Speed Wind Generator," in IEEE Transactions on Industrial Electronics, vol. 53, no. 4, pp. 1074-1085, June 2006.

[15] P. Mukherjee and V. V. Rao, "Superconducting magnetic energy storage for stabilizing grid integrated with wind power generation systems," in Journal of Modern Power Systems and Clean Energy, vol. 7, no. 2, pp. 400-411, March 2019.

[16] B. Yang et al., "Control of superconducting magnetic energy storage systems in grid-connected microgrids via memetic salp swarm algorithm: An optimal passive fractional-order PID approach," in
IET Generation, Transmission \& Distribution, vol. 13, no. 24, pp. 5511-5522, 17122019.

[17] S. C. Tripathy, R. Balasubramanian and P. S. C. Nair, "Effect of superconducting magnetic energy storage on automatic generation control considering governor deadband and boiler dynamics," in IEEE Transactions on Power Systems, vol. 7, no. 3, pp. 1266-1273, Aug. 1992.

[18] R. I. Dunn, P. J. Hearps and M. N. Wright, "MoltenSalt Power Towers: Newly Commercial Concentrating Solar Storage," in Proceedings of the IEEE, vol. 100, no. 2, pp. 504-515, Feb. 2012.

[19] T. P. Kumar, S. D. Kumar, D. Josesph, and R. J. Kumar, "Fresnel Solar Power using molten salt Concentrated Solar Power," 2013 International Conference on Green Computing, Communication and Conservation of Energy (ICGCE), Chennai, 2013, pp. 488-493.

[20] S. Lemofouet and A. Rufer, "A Hybrid Energy Storage System Based on Compressed Air and Supercapacitors With Maximum Efficiency Point Tracking (MEPT)," in IEEE Transactions on Industrial Electronics, vol. 53, no. 4, pp. 1105-1115, June 2006.

[21] M. J. Ghadi et al., "Day-Ahead Market Participation of an Active Distribution Network Equipped with Small-Scale Compressed Air Energy Storage Systems," in IEEE Transactions on Smart Grid.

[22] D. J. Swider, "Compressed Air Energy Storage in an Electricity System with Significant Wind Power Generation," in IEEE Transactions on Energy Conversion, vol. 22, no. 1, pp. 95-102, March 2007.

[23] K. Aoki, M. Itoh, T. Satoh, K. Nara, and M. Kanezashi, "Optimal long-term unit commitment in large scale systems including fuel constrained thermal and pumped-storage hydro," in IEEE Transactions on Power Systems, vol. 4, no. 3, pp. 1065-1073, Aug. 1989.

[24] Ning Lu, J. H. Chow, and A. A. Desrochers, "Pumped-storage hydro-turbine bidding strategies in a competitive electricity market," in IEEE Transactions on Power Systems, vol. 19, no. 2, pp. 834-841, May 2004.

[25] S. Xia, Z. Ding, T. Du, D. Zhang, M. Shahidehpour, and T. Ding, "Multi-time scale coordinated scheduling for the combined system of wind power, photovoltaic, thermal generator, hydro pumped storage and batteries," in IEEE Transactions on Industry Applications.

[26] L. Chen, J. Wang, Z. Sun, T. Huang, and F. Wu, "Smoothing Photovoltaic Power Fluctuations for Cascade Hydro-PV-Pumped Storage Generation System Based on a Fuzzy CEEMDAN," in IEEE Access, vol. 7, pp. 172718-172727, 2019.

[27] H. Qian, J. Zhang, J. Lai, and W. Yu, "A highefficiency grid-tie battery energy storage system," in IEEE Transactions on Power Electronics, vol. 26, no. 3, pp. 886-896, March 2011. 
[28] N. Padmanabhan, M. Ahmed, and K. Bhattacharya, "Battery Energy Storage Systems in Energy and Reserve Markets," in IEEE Transactions on Power Systems, vol. 35, no. 1, pp. 215-226, Jan. 2020.

[29] U. Datta, A. Kalam and J. Shi, "Battery Energy Storage System Control for Mitigating PV Penetration Impact on Primary Frequency Control and State-of-Charge Recovery," in IEEE Transactions on Sustainable Energy, vol. 11, no. 2, pp. 746-757, April 2020.

[30] Cole, Wesley, and A. Will Frazier, Cost Projections for Utility-Scale Battery Storage, 2019, Golden, CO: National Renewable Energy Laboratory. NREL/TP6A20-73222, available at https://www.nrel.gov/docs/fy19osti/73222.pdf.

[31] Chen, H., Cong, T., Yang, W., Tan, C., Li, Y. and Ding, Y., 2009. Progress in electrical energy storage system: A critical review. Progress in Natural Science, 19(3), pp.291-312.

[32] IEEE Smart Grid Battery Storage Working Group, "Battery Storage Systems", Whitepaper, available at:

https://smartgrid.ieee.org/images/files/pdf/battery_storage _whitepaper.pdf

[33] M. Faisal, M. A. Hannan, P. J. Ker, A. Hussain, M. B. Mansor, and F. Blaabjerg, "Review of Energy Storage System Technologies in Microgrid Applications: Issues and Challenges," in IEEE Access, vol. 6, pp. 35143-35164, 2018.

[34] Hasan Abumeteir and Mete Vural, "The Determining Factors of Selecting Energy Storage Systems for the Renewable Energy Sources in the Energy- Efficient Building”, October 2016 Conference, 6th International Engineering Conference on Energy-Efficient Buildings, Islamic University of Gaza, pp. 96-101.

[35] M. T. Al-Nory and M. El-Beltagy, "Optimal selection of energy storage systems," 2015 Saudi Arabia Smart Grid (SASG), Jeddah, 2015, pp. 1-6.

[36] B. F. Nunes, Y. F. F. C. Silva and E. C. Bortoni, "Optimized selection and operation of electrical energy storage systems," 2015 IEEE Power \& Energy Society General Meeting, Denver, CO, 2015, pp. 1-5.

[37] M. Farhadi and O. Mohammed, "Energy storage systems for high power applications," 2015 IEEE Industry Applications Society Annual Meeting, Addison, TX, 2015, pp. 1-7.

[38] T. J. Hammons and A. G. Geddes, "Assessment of alternative energy sources for generation of electricity in the UK following privatization of the electricity supply industry," in IEEE Transactions on Energy Conversion, vol. 5, no. 4, pp. 609-615, Dec. 1990.

[39] Lu, B., Stocks, M., Blakers, A. and Anderson, K., 2018. Geographic information system algorithms to locate prospective sites for pumped hydro energy storage. Applied Energy, 222, pp.300-312.
[40] International Hydropower Association. (2018). The world's water battery: Pumped hydropower storage and the clean energy transition. Available at:

https://www.hydropower.org/publications/the-world'swater-battery-pumped-hydropower-storage-and-theclean-energy-transition

[41] Robinson, C., Werwer, A., El-Baz, F., El-Shazly, M., Fritch, T. and Kusky, T., 2006. The Nubian Aquifer in Southwest Egypt. Hydrogeology Journal, 15(1), pp.33-45. https://doi.org/10.1007/s10040-0060091-7

[42] El Nahry, A. H., Elewa, H. H., Qaddah, A. A., and Gedida, N. "Soil and groundwater capability of East Oweinat area, Western Desert, Egypt using GIS spatial modeling techniques", Nature and Science, 2010; 8(8), available at:

http://www.sciencepub.net/nature.

[43] M. Elarabawy and P. Tosswell, "An appraisal of the Southern Valley Development Project in Egypt", Journal of Water Supply: Research and Technology-AQUA, vol. 47, no. 4, pp. 167-175, 1998. Available: 10.2166/aqua.1998.24.

[44] MOHAMED E. A. KHALIFA and SAMIR M. H. ABD EL-RHMAN, "Land Potentiality Assessment, East El-Owienat Area, Egypt", Journal of Agriculture and Environment Science, Alexandria.University., Egypt, Vol.7 (1), 2008 149161, available at:

http://www.damanhour.edu.eg/pdf/agrfac/Root1/Vol7_1_ 7.pdf

[45] N. Al Khudhiri, S. S. Dol and M. S. Khan, "Design of hydro-power plant for energy generation for a mid-size farm with insufficient water distribution networks," 2018 Advances in Science and Engineering Technology International Conferences (ASET), Abu Dhabi, 2018, pp. 1-6.

[46] N. K. Singh and S. S. Badge, "A novel two-layer constant power control strategy for a renewable energy system with reversible pumped hydro storage," 2017 International Conference on Intelligent Computing, Instrumentation and Control Technologies (ICICICT), Kannur, 2017, pp. 16471651.

[47] A. A. Snchez de la Nieta, J. Contreras, J. I. Muoz, and J. P. S. Catalo, "Optimal Wind Reversible Hydro Offering Strategies for Midterm Planning," in IEEE Transactions on Sustainable Energy, vol. 6, no. 4, pp. 1356-1366, Oct. 2015.

[48] R. O. Florez and J. A. A. Jimenez, "Reversibles Hydromaquines Aplicated to Microhydropower," in IEEE Latin America Transactions, vol. 6, no. 2, pp. 170-175, June 2008.

[49] K. Shim et al., "Estimation of Conservation Voltage Reduction Factors Using Measurement Data of KEPCO System", Energies, vol. 10, no. 12, pp. 2148-2017. Available at: 10.3390/en10122148.

[50] C. T. Gaunt, "Scope for research and development in low voltage distribution design," in the Proceedings 
of IEEE. AFRICON '96, Stellenbosch, South Africa, 1996, pp. 326-330 vol.1.

[51] R. P. Dewi, B. Anggoro and B. Halimi, "Francis Turbine Design on Malabar Mini Hydropower Plant," 2018 Conference on Power Engineering and Renewable Energy (ICPERE), Solo, Indonesia, 2018, pp. 1-4.

[52] Shouman, Enas R., Hesham Ezz, and Emad S. Bakhoum. "Economic Analysis of the Using of Traditional Fuel and Solar Energy to Power Irrigation Pumps in Egypt." International Journal of Engineering Research in Africa, vol. 38, September 2018, pp. 87-99.

https://doi.org/10.4028/www.scientific.net/jera.38.87

[53] S. Biswas and M. Iqbal, "Dynamic Modelling of a Solar Water Pumping System with Energy Storage", Journal of Solar Energy, vol. 2018, pp. 1-12, 2018. Available: 10.1155/2018/8471715.

[54] E. Nshimyumuremyi, "Solar Water Pumping System in Isolated Area to Electricity: The Case of Mibirizi Village (Rwanda)", Journal of Smart Grid and Renewable Energy, vol. 06, no. 02, pp. 27-39, 2015. Available: 10.4236/sgre.2015.62003.

[55] Sclida.en.alibaba.com, 2020. [Online]. Available: https://sclida.en.alibaba.com , [Accessed: 24- Apr- 2020].

[56] Al Nasr for Solar Energy, https://nasrsolar.com/ [Accessed: 25- Apr- 2020].

[57] AliExpress,

https://ar.aliexpress.com/?spm=a2g0o.detail.1000002.1.6 9e22f390X8DGq [Accessed: 26- Apr- 2020].

[58] Immendoerfer, A., Tietze, I., Hottenroth, H. et al. Life-cycle impacts of pumped hydropower storage and battery storage. International Journal of Energy and Environment Engineering, Springer, 2017, vol. 8, pp. 231-245. https://doi.org/10.1007/s40095-017$0237-5$

[59] C. Hossain, N. Chowdhury, M. Longo, and W. Yaïci, "System and Cost Analysis of Stand-Alone Solar Home System Applied to a Developing Country", in Sustainability, vol. 11, no. 5. 1403, 2019. Available at:

https://doi.org/10.3390/su11051403

[60] M. Bruch and M. Müller, "Calculation of the Costeffectiveness of a PV Battery System", in Energy Procedia, vol. 46, pp. 262-270, 2014. Available:

https://doi.org/10.1016/j.egypro.2014.01.181.

[61] "Energy Storage Technology and Cost Characterization Report", U.S. Department of Energy Office of Scientific and Technical Information, Oak Ridge, 2019, available at http:/www.osti.gov

[62] Coutu A., Marier S., Chamberland-Lauzon J., Monette C., "Designing Francis runners for 0-100 percent operation", in Proceeding of Hydro 2015, Bordeaux, France, October 2015, available at https://www.andritz.com

[63] M Gagnon, S A Tahan, P Bocher and D Thibault, "Impact of startup scheme on Francis runner life expectancy." IOP conference series: earth and environmental science. vol. 12. No. 1. IOP Publishing, 2010. p. 012107, available at

https://iopscience.iop.org/article/10.1088/1755$1315 / 12 / 1 / 012107$

[64] K. Sangani, "Battery recycling," in Engineering and Technology, vol. 6, no. 12, pp. 53-55, January 2012.

[65] L. Chuan and A. Ukil, "Modeling and Validation of Electrical Load Profiling in Residential Buildings in Singapore," in IEEE Transactions on Power Systems, vol. 30, no. 5, pp. 2800-2809, Sept. 2015.

[66] Dr. Massad Qutb Hassanein and etal, Deficit Irrigation Management for the main crops in Egypt under current and future conditions, book (in Arabic), Central Laboratory for Agricultural Climate, Agricultural Research Center, Egypt, April 2013, pp 105-106.

\section{Appendix A: Daily loads of an average country-side house}

To determine the daily energy consumption of a country-side house, the data given in [65] was considered as shown in Table A.1.

Table A.1. Daily loads of an average country-side house

\begin{tabular}{|l|c|c|c|c|c|}
\hline $\begin{array}{l}\text { Electric } \\
\text { Loads }\end{array}$ & $\begin{array}{c}\text { Powe } \\
\text { r [w] }\end{array}$ & Quantity & $\begin{array}{c}\text { Hours } \\
\text { per day }\end{array}$ & $\begin{array}{c}\text { Total } \\
\text { Power } \\
{[\mathbf{W}]}\end{array}$ & $\begin{array}{c}\text { Energy } \\
\text { per day } \\
{[\mathbf{W h}]}\end{array}$ \\
\hline $\begin{array}{l}\text { Washing } \\
\text { machine }\end{array}$ & 200 & 1 & 1 & 200 & 200 \\
\hline $\begin{array}{l}\text { Refriger } \\
\text { ator }\end{array}$ & 200 & 1 & 24 & 200 & 4800 \\
\hline $\begin{array}{l}\text { TV }+ \\
\text { Receiver }\end{array}$ & 35 & 1 & 8 & 35 & 280 \\
\hline Fan & 100 & 3 & 12 & 300 & 3600 \\
\hline Blender & 400 & 1 & 1 & 400 & 400 \\
\hline $\begin{array}{l}\text { Led } \\
\text { Lamps }\end{array}$ & 9 & 6 & 12 & 54 & 648 \\
\hline iron & 1000 & 1 & 0.25 & 1000 & 250 \\
\hline radio & 10 & 1 & 12 & 10 & 120 \\
\hline $\begin{array}{l}\text { Led } \\
\text { Lamps }\end{array}$ & 24 & 3 & 12 & 72 & 864 \\
\hline & & & Total & $\mathbf{2 2 7 1}$ & $\mathbf{1 1 1 6 2}$ \\
\hline
\end{tabular}

The Average power required for a single home $=11162$ / $24=465.08 \mathrm{~W}$

Considering a Diversity factor $=1.1$ and a Group Diversity factor $=1.1[49,50]$, the average power required for a single home $=465.08 / 1.3=357.8 \mathrm{~W}$ and the power required for 10 homes $=10 \times 357.8 / 1.1=$ $3252.7 \mathrm{~W}$

\section{Appendix B: Electrical Machines of the site}

The site contains:

1. Electric agricultural grain grinding machine

The electric grain grinding machine has a power rating of $3 \mathrm{hp}$ and grinds all types of grains such as corn, barley, broad beans, fodder, and farm wastes. It grinds from 150 to $200 \mathrm{~kg}$ per hour [19].

\section{Fixed spray irrigation water pump}


When growing the main crops such as (wheat - barley alfalfa - peanuts - sunflower - corn - sesame), irrigation with fixed sprinklers is preferred.

It is used to irrigate 10 acres (185 x 250) meters. We need a pump for irrigation water with engine POWER of at least $20 \mathrm{hp}$ [20], that is, we need 5 engines to irrigate 50 acres with total POWER $=100 \mathrm{hp}=74569.99$ watts.

Table B.1. Daily consumption of the selected electrical machines

\begin{tabular}{|c|c|c|c|c|c|}
\hline $\begin{array}{c}\text { Agricultural } \\
\text { machinery }\end{array}$ & $\begin{array}{c}\text { Power } \\
{[W]}\end{array}$ & Quantity & $\begin{array}{l}\text { Hours/ } \\
\text { day }\end{array}$ & $\begin{array}{c}\text { Po } \\
\text { wer } \\
{[W]}\end{array}$ & $\begin{array}{c}\text { Ener } \\
\text { gy } \\
\text { day } \\
{[\text { Wh] }}\end{array}$ \\
\hline $\begin{array}{c}\text { Agricultural } \\
\text { grain milling } \\
\text { machine }\end{array}$ & $\begin{array}{c}2237 \\
1\end{array}$ & 1 & 1 & $\begin{array}{c}223 \\
7.1\end{array}$ & $\begin{array}{c}2237 . \\
1\end{array}$ \\
\hline $\begin{array}{l}\text { Irrigation } \\
\text { water pump } \\
\text { for fixed } \\
\text { spraying } \\
\end{array}$ & 14914 & 5 & 0.25 & $\begin{array}{l}372 \\
8.5\end{array}$ & $\begin{array}{c}18642 \\
.5\end{array}$ \\
\hline & & & Total & $\begin{array}{c}601 \\
5.6\end{array}$ & $\begin{array}{c}20879 \\
.6\end{array}$ \\
\hline
\end{tabular}

The average power required per day $=20879.6 / 24=$ $869.98 \mathrm{~W}$. Then, the total power required for the selected electrical machines per day is $869.98 / 1.1=790.9 \mathrm{~W}$.

\section{Appendix C: Water Needs}

\section{C.1. Daily water needs for irrigation}

Specific crops were identified based on the nature of the site and the inhabitants. These crops and their water needs are shown in Table C1 [66].

Table C1: Water needs for irrigating the selected

\begin{tabular}{|c|c|c|c|}
\hline \multicolumn{4}{|c|}{ crops } \\
\hline Crop & $\begin{array}{c}\text { Water } \\
{\left[\mathbf{m}^{3} / \text { acre }\right]}\end{array}$ & $\begin{array}{c}\text { Water } \\
{\left[\mathrm{m}^{3} / \text { acre/year }\right]}\end{array}$ & $\begin{array}{c}\text { Water } \\
{\left[\mathrm{m}^{3} / \text { acre/day }\right]}\end{array}$ \\
\hline $\begin{array}{l}\text { Barley } \\
\text { (Winter) }\end{array}$ & 321.9 & \multirow{2}{*}{659.7} & \multirow{2}{*}{1.8} \\
\hline $\begin{array}{l}\text { Peanuts } \\
\text { (Summer) }\end{array}$ & 337.8 & & \\
\hline $\begin{array}{l}\text { Municipal } \\
\text { Beans } \\
\text { (Winter) }\end{array}$ & 217.8 & \multirow{2}{*}{916.7} & \multirow{2}{*}{2.5} \\
\hline $\begin{array}{l}\text { Yellow } \\
\text { corn } \\
\text { (Summer) }\end{array}$ & 698.9 & & \\
\hline $\begin{array}{l}\text { Alfalfa } \\
\text { (permanent) }\end{array}$ & 238.6 & 283.6 & 0.65 \\
\hline
\end{tabular}

The crops are distributed in acres and their needed amounts of water per day are shown in Table C2.
Table C2. Distribution of Crops through 50 acres

\begin{tabular}{|l|c|c|}
\hline Crops & Acres & $\begin{array}{c}\text { Water } \\
{\left[\mathbf{m}^{\mathbf{3} / \mathbf{d a y}]}\right]}\end{array}$ \\
\hline Barley + Peanuts & 20 & 36 \\
\hline $\begin{array}{l}\text { Municipal Beans + Yellow } \\
\text { Corn }\end{array}$ & 20 & 50.2 \\
\hline Alfalfa & 10 & 6.5 \\
\hline \multicolumn{2}{|c|}{ The total amount of water for 50 acres } & 92.7 \\
\hline
\end{tabular}

\section{C.2. Daily water needs for Drinking}

These amounts of water include both individuals and some rural animals are shown in Table C3 [C1].

Table C3. Water requirements for a country house

\begin{tabular}{|l|c|c|c|}
\hline Item & $\begin{array}{c}\text { Average } \\
\text { Consumption } \\
\text { (Liters/head/day) }\end{array}$ & Quantity & $\begin{array}{c}\text { Total } \\
\text { Consumpti } \\
\text { on } \\
\text { (Liters/day) }\end{array}$ \\
\hline $\begin{array}{l}\text { Rural } \\
\text { Family }\end{array}$ & 190 & 4 & 760 \\
\hline $\begin{array}{l}\text { Dairy } \\
\text { cow }\end{array}$ & 114 & 2 & 228 \\
\hline $\begin{array}{l}\text { Sheep } \\
\text { and } \\
\text { goats }\end{array}$ & 8 & 10 & 80 \\
\hline Calf & 41 & 1 & 41 \\
\hline Poultry & 0.45 & 50 & 23 \\
\hline Cattle & 57 & 1 & 57 \\
\hline Rabbit & 0.2 & 10 & 2 \\
\hline Total consumption for $1 \mathrm{house}^{2}=10 \times 1191$ Litres/day \\
\hline \multicolumn{4}{|c|}{$=11.91 \mathrm{~m}^{3} /$ day } \\
\hline
\end{tabular}

Thus, the total amount of water for irrigation and drinking is $92.7+11.91=104.6 \approx 105 \mathrm{~m}^{3} /$ day. Considering two days of autonomy, then the amount of water becomes $210 \mathrm{~m}^{3}$. To store such amount of water, a cylindrical reservoir will be built with a diameter of $10 \mathrm{~m}$ and a height of $3 \mathrm{~m}$.

\section{Appendix D: Characteristics of the selected PM module}

Maximum Power $\left(P_{\max }\right)$

Open Circuit Voltage ( Voc )

Short Circuit Current $\left(I_{\mathrm{sc}}\right)$

Maximum Power Voltage ( $\left.V_{\mathrm{mp}}\right)$

Maximum Power Current ( $I_{\mathrm{mp}}$ )
$260 \mathrm{~W}$

$38.10 \mathrm{~V}$

$8.91 \mathrm{~A}$

$30.87 \mathrm{~V}$

$8.42 \mathrm{~A}$ 